\title{
Towards a Counter-narrative: Why Dissent/ Agonism Might have Appeal in a Neoliberal Higher Education Space!
}

Suriamurthee Moonsamy Maistry

http://orcid.org/0000-0001-9623-0078

\section{Sylvan Blignaut}

http://orcid.org/0000-0002-5514-0604

\section{Petro Du Preez}

https://orcid.org/0000-0002-9100-6461

Lesley Le Grange

https://orcid.org/0000-0002-7096-3609

Labby Ramrathan

https://orcid.org/0000-0001-9963-0675

\section{Shan Simmonds}

http://orcid.org/0000-0001-5005-9906

\section{Abstract}

In this article, we provoke the question as to the potentiality of dissent in a neoliberal higher education assemblage circumscribed within the metaassemblage of late global capitalism. We offer a counter-intuitive exploration of the much-vaunted post-apartheid South African fetish, social cohesion, to argue that such ideological imperatives, when institutionalised and theorised 
in and through higher education, run the risk of developing false consciousness, a temporal pseudo-engagement that unwittingly reasserts the master narrative, namely that of self-absorbed, neoliberal pursuits. While we maintain our loyalty to the greater higher education project in South Africa, our contemplation is for an agonism that maintains a necessary attentiveness in a rapidly changing, performative arena.

Methodologically, we consider figurational fugue as contrapuntal, polyphonic composition comprising a sequence of six individual personal narratives that are subjected to a diffractivity, an attending to difference with a view to analysing dissent as productive and generative. We invoke Mouffe's (2013) agonistics - the notion of an antagonistic logic that challenges liberal democratic notions of social cohesion, one that contests the domesticating nature of the aggregative harmonious that liberal social cohesion falls foul of. We contend that social cohesion's rational consensus seeking is unproductive in South African higher education. We argue instead for a deliberative conflictual consensus that is dialogic and generative: a Deleuzian higher education (curriculum) space that is perennially dissonant and encourages rhizomatic dissent, and provocative, yet productive, encounters.

Keywords: agonism, antagonism, dissent, figurational fugue, higher education, neoliberalism, social cohesion

\section{Introduction}

... pluralism is not merely a fact, something that we must bear grudgingly or try to reduce, but an axiological principle. It is taken to be constitutive at the conceptual level ... as something that we should celebrate and enhance .... (It) gives a positive status to differences and questions the objective of unanimity and homogeneity, which is always revealed as fictitious and based on acts of exclusion (Mouffe 2000b:19).

In a compelling article titled Deliberative Democracy or Agonistic Pluralism, Chantal Mouffe argues that 'democratic theory needs to acknowledge the ineradicability of antagonism and the impossibility of achieving a fully 
inclusive rational consensus' (Mouffe 2000a:4). We draw on Mouffe's argument in this article to reflect on our experiences as academics in the South African higher education sector. We contend that social cohesion as a national imperative, while serving a consensus seeking agenda, falls foul of a sub-text of subtle yet persuasive control of dissenting voices.

Social cohesion as a post-apartheid political ideology has particular appeal. It has been the powerful aspiration of respected politicians like Nelson Mandela and social/religious figures like Archbishop Desmond Tutu. The strong appeal of the rainbow nation metaphor, an image reflecting the racial diversity constituting the new South African nation, lies in its suggestion of a place for all South Africans in the new political dispensation. However, at that time (and still now), the call was to develop a new unifying national identity. Note that a naturally occurring rainbow is caused by refraction and reflection of light as it passes through tiny droplets of water. It is, in essence, an intangible optical illusion, one that might be likened to the reality that many South Africans experience as they struggle for both economic and social space in post-apartheid South Africa (Habib 2013; Zulu 2013). The previously disenfranchised, however, were/are implored to acknowledge and comply with the new rule of engagement, namely nonadversarial or non-confrontational social solidarity.

Arguably the state's most subtle and powerful ideological move is the vectoring of the nation along neoliberal tenets (Van Niekerk \& Padayachee 2019). From an international perspective, the marketisation of higher education remains salient. Some of its proponents argue for the efficiency of resource application that competition brings, while its opponents contend that the Humboldtian ideal is subsumed by an instrumental economic growth imperative (Brown 2011) and the eventual degradation of education (Fanelli \& Evans 2015). For the purpose of this article, we focus first on how the South African higher education space in which we work has become subject to the doctrine (economic theory) of the market and how dissent and agonism are necessary to counter such insurgence.

The corporatization and marketisation of the SA higher education sector have seen the rapid repositioning of universities as servants to the economy. Managers of human resources and finance occupy strategic leadership positions in university executive structures as well as in the university senate, the traditional domain of intellectualism and scholarly 
deliberation. A neoliberal performance ideology has infiltrated higher education without difficulty, instituting, for example, industry-style formulas that have now become the norm for quantifying the rich qualitative work of academics. Competition for resources (students and personnel) within and across universities, as seen, for instance, in the annual parade of league tables of multiple performances including local and international university rankings, has become the new normal in a Foucauldian sense.

The second focus relates to the peculiar intersectional social justice issues that continue to plague the nation as it grapples with race, gender and economic inequality. These issues play themselves out in particular ways at the institutions that we inhabit, where transformation (and recent decolonial) endeavours have become institutionalised (Lange 2014). Singh (2012) reminds us that transformation is clouded by narrow understandings of better positioning of universities to serve the economy. The South African university sector has become a fractious site of recurring student (and staff) protests with some prophesising its demise should concerted reparation and authentic reconciliation not occur (Jansen 2017).

In this kind of context, we argue that consensus seeking becomes a complex phenomenon that is always mediated by the relative power that consensus seekers bring to consensus-seeking initiatives. That the postapartheid South African higher education sector has undergone somewhat radical reconfiguration, is indisputable (Jansen 2017). The merging of universities and Technikons (institutions that offered technical vocational education and training at post-school level), was a watershed moment for the country's higher education system, a system that was previously in line with particularly racialised architecture. In many instances, new amalgams and regional mergers were 'arranged marriages' in which non-consenting partners were forced together by this state-driven initiative.

In this article, we embark on an ambitious agglomeration of experience, using the metaphor of the fugue to address the notion of how an antagonistic logic might challenge liberal democratic notions of social cohesion, towards a productive agonistic deliberative.

\section{Democratic Agonism and Dissent: Mouffe's Conceptual Inspiration}

Democratic agonism or agonistic democracy in the last few decades should 
be seen as part of the effort to revitalise democracy in the face of the reascendency of neoliberalism and contestation/conflict in divided societies. Theories of democratic agonism provide an alternative to liberal rationalism and Habermasian deliberative democracy. Harvey (2012) argues that liberal rationalists contend that wide agreement on political norms and institutions requires that citizens bracket their particular religious, social and moral beliefs when making decisions on constitutional matters. In other words, this form of democracy is based on procedural or aggregative reasoning. Habermas (1996) sees traditional democratic discourse, which focuses on aggregative or procedural reasoning, as inadequate. Therefore, he argues for the extension or deepening of democracy to establish 'deliberative democracy' (Habermas 1996). In this model, solutions to conflict should be the outcome of deliberation (free, public reasoning among equals). However, although Habermas's deliberative model does extend democracy, the model is based on reaching consensus. In other words, even though all citizens deliberate as free and equal persons, decisions are made by reaching agreement. Both deliberative democrats and democratic agonists hold the view that democracy is more than its frills and institutions (e.g. elections, parliament and rule of law) and it should thus ensure inclusive democratic processes in all spheres of social life and public institutions (Harvey 2012).

However, democratic agonists find the consensus orientation of the deliberative democratic model inadequate. As Mouffe (2000a:17) writes,

the ideal of a pluralist democracy cannot be to reach a rational consensus in the public sphere. Such a consensus cannot exist. We have to accept that every consensus exists as a temporary result of a provisional hegemony.

Consensus entails, even if temporarily, the stabilization of power, which involves some form of exclusion. In contrast, Mouffe (2000a) argues that power cannot be dissolved through rational debate, and her vision of agonistic democracy (pluralism) is one that lays bare the forms of exclusion that power relations under rationality and morality conceal.

Here, it is apposite to highlight two forms of power articulated by Spinoza (2001): postestas and potentia. Postetas is power that is hierarchical, hegemonic, coercive, transcendent and colonising. It is the power of empire. Potentia is the power that connects, that liberates, that is immanent and life 
enhancing. It is the power of the multitude. We see dissent as driven by potentia. However, potentia can become postestas and vice versa. When what the multitude does is no longer life enhancing, then potentia has become postestas, and dissent no longer means loyal agreement.

Tully (1999:170) argues that theories of democratic agonism provide an alternative vision of democracy, in which the tenets of democracy are always 'open to question, disagreement, contestation, deliberation, negotiation and change of time'. For Mouffe (2005), radical democracy implies a space where different political hegemonic projects can be confronted, and difference and the expression of social plurality can be acknowledged. Given that relations of power are constitutive of the social-democratic politics should not seek to eliminate power, but to constitute power in ways that are aligned to radical democratic values. Mouffe (2000a) underlines the role of democratic politics in transforming antagonism to agonism. She avers that antagonism is the struggle between enemies whereas agonism is the struggle between adversaries. The struggle between enemies aims at defeating the ideas, beliefs and interpretations of the enemy. In contrast, agonistic pluralism seeks to defend the different ideas, beliefs and interpretations of the adversary. Agonistic democracy, therefore, sees the aim of democratic politics as mustering such passions towards democratic praxis, not eliminating passions from the public sphere in the interests of rational consensus (Mouffe 2000a).

We argue that deliberative democracy is based on assent, because consensus is reached through agreement, even if the consent is provisional, whereas agonistic democracy is based on dissent, because the beliefs, interpretations and ideas of adversaries are defended and viewed as essential to sustaining democracy. However, just as there is a nuanced difference between antagonism and agonism, there is a nuanced difference between disagreement and dissent. Dissent is loyal disagreement. McDonough (2010) describes it as the liminal space where association remains, despite some level of fundamental difference. In other words, even though participants in a praxis might differ from one another they remain loyal to the praxis or project. For example, although curriculum scholars might differ from one another they remain committed to advancing the field of Curriculum Studies. Alternatively, scholars at a university might differ from one another and robustly so, but remain committed to advancing higher education in all its forms and functions in the interest of the public good. But is dissent always 
productive? Would we characterise the recent insurrection at the US Capitol as dissent? McDonough (2010) argues that dissent is essentially ethical. To be otherwise would lead to erosion or neutralization, as might be the case with the insurrection at the US Capitol.

For McDonough (2010) dissent is productive when it promotes justice, when it is the most justifiable in particular circumstances, and if the content of the dissent is ethical. For us, dissent is ethical when human actions contribute to the advancement of life; not only human life, but all of life. We contend that when dominant paradigms (such as the neoliberal capitalist one), which erodes kinship networks and destroys the environment are challenged, then productive lines of connection among humans and between humans and the more-than-human world can be invigorated. Moreover, we contend that dissent as an ethical act counteracts any a priori ethical rules or guidelines so that dissent is immanent in the activities humans engage with, and immanent to being and becoming. Dissent is immanent to human becoming, such as the becoming of human activities or organisations. Moreover, dissent is rhizomatic in the sense that we will never know what it will or could do. Like the rhizome figuration, it has no beginning or end and can develop along new or old lines and in any direction (Le Grange 2011). It is therefore only with hindsight that we can gain some insight into moments when dissent has immanently been present in our becoming as scholars/academics and the becoming of the organizations we have inhabited or that inhabit us.

\section{Invoking Fugue: A Brief Methodological Note ...}

Braidotti (2013) criticises the extent to which neo-liberalism has invaded research paradigms and/or agendas, to such an extent that most research is nothing more than data-mining exercises. In such instances, she continues, research has 'entered a zombified landscape of repetition without difference and lingering melancholy' (Braidotti 2013:5). One such example could be drawn from narrative inquiry (the very method of data generation that we employ in this study), because it has been critiqued for merely re-storying that does not move beyond the reproductive realm (Hill 2017). (Post)qualitative inquiry aligns with this critique, because narrative inquiry has the propensity to become merely contextual repetition without a robust engagement with the embedded, embodied and embrained nature of the 
performative side of narratives (see, for example, Lather 2013; Aronsson \& Taguchi 2018; Kumm \& Berbary 2018; Le Grange 2018a). Because of the latter, our continued use of narrative inquiry must transcend the narrow confines of analysing data from an interpretivist tradition that uses methods such as coding, clustering and thematising. In this regard, Jackson and Mazzei (2012) argue for an approach in which data are thought through with theory to enable multiple perspectives to emerge from the qualitative data. These authors argue that when we 'plug' one text into another ... we are situating ourselves at the threshold. In positioning themselves at the threshold, Jackson and Mazzei (2012:6) argue that,

[t]he data were not centered or stabilized, but used as brief stopping points and continually transformed, and exceeded, as we used theory to turn the data into something different, and we used data to push theory to its limit.

In attempting to harness the experience of six mid- and late-career university academics, we 'experiment' using a musical fugue, a multi-voiced composition (Jones \& Adams 2014) as the framing architecture for this article. Our experiences, while comprising elements of similarity, are also quite disparate, given our dissimilar historicities and facticities. Fugue has particular appeal as it accommodates the contrapuntal, polyphonic, akin to the varied personal narratives that we generate and perform that support the arguments that this article leads. We attempt a polyphonic composition in which several melodic lines (narratives) are heard, but none is afforded preeminence. The sequencing of the melodic lines is random, deliberately discordant (contrapuntal), in line with the argument that this article attempts to lead to, namely that of dialectical agonism - musical counterpoints in which interdependent harmonic lines synchronise, but each maintains and retains its unique rhythm and melodic architecture.

A diffractive analysis has been used to make sense of the contrapuntal melodic lines as we played through them and 'harmonised' the separate lines to invoke the fugue. Diffraction, a term borrowed from physics, literally refers to the way in which waves combine when they overlap and the subsequent bending and spreading of waves that occur as a result of an encounter or obstruction (Barad 2007). Applied to the social sciences, this figuration has methodological potential as an 'effective tool for 
thinking about social-natural practices in a performative rather than a representationalist mode' (Barad 2007:88).

(Post)qualitative inquiry approaches to research surpass conventional, orthodox techniques that over-emphasise the 'how' and regulate what counts as knowledge (Kumm \& Berbary 2018) and could, through a diffractive analysis of melodic lines, afford opportunities for researchers to improvise along the way. Kumm and Berbary (2018) state that such an approach is not about using theory as an a priori staging for research, nor as an a posteriori lens. It is thus not representationalist, but performative and can therefore not be captured in prescriptive, instrumentalist theoretical and/or methodological conclusions. Thus, as a method, diffraction enables the bringing together of contrapuntal melodic lines so that a new fugue can surface (Hepler et al. 2019). We maintain that new fugues emerge when the world is understood from within, 'as a critical practice of engagement' and 'thinking insights from scientific and social theories through one another' (Barad 2007:90, 92). For Barad (2007:92) reading diffractively is not when two or more texts are read 'against each other' or in a 'bidirectional' way, but rather when the understandings generated from different texts are brought into 'conversation with one another'.

In this article we depart from conventional understandings of validity and invoke what Lather (1994:45) termed 'rhizomatic validity'. Lather (1994:45) argues that to act rhizomatically,

is to act via relay, circuit, multiple-openings, as crabgrass in the lawn of academic preconceptions ... There is no trunk, no emergence from a single root, but rather arbitrary branchings off and temporary frontiers that can only be mapped, not blueprinted ... Rhizomatics are about the move from hierarchies to networks and the complexity of problematics where any concept, when pulled, is recognised as connected to a mass of tangled ideas, uprooted, as it were, from the epistemological field.

Therefore, we shall experiment with pulling the concept dissent visà-vis the neoliberal university in different directions to make connections with theory, life histories and lived experiences. We do not aim to replicate but to proliferate, to keep ideas, theories, concepts in constant flow, so that they - like us - are always in-becoming. 


\section{Towards the Composition of a Polyphonic, Contrapuntal Melody ...}

\subsection{Tune 1}

I am a middle-class, South African, male university academic of Indian descent, not indigenous to the country; yet I know no other place on earth I can call home. I consider my constantly morphing identity as that of border inhabitant (Anzaldúa 1987), a subject who inhabits and understands the metaphorical border as fluid, yet as inherently contradictory and productive. Born in SA 56 years ago, and having lived my formative years under apartheid means that I still carry much of it learnt through socialization. Like many non-white South Africans, my parents endured the social and economic brutality of the apartheid regime, much of which I witnessed firsthand.

I remain convinced that South Africa's 'abnormality' had transmutated beyond 1994. Whereas under apartheid, the enemy was overt and tangible, in the new SA, the antagonistic friend-enemy binary became somewhat opaque. In Mouffe's discourse, this phenomenon might be argued as requiring a reconceptualizing of the substance of the relationship from antagonism to agonism in which the 'new' enemy might now be viewed as adversary (Mouffe 2005). This epiphanic moment is significant as one now had to couch one's activism within fluid and emerging new rules of engagement. In my view, the post-apartheid regime simply retained the western, Eurocentric university grand design and unapologetically accelerated the swing to neoliberal market-oriented principles over the last 25 years. It thus begs the question as to how to position oneself as activist in this 'evolving' higher education milieu.

As an academic, I attempt to use my position to frame my work (teaching and research scholarship) in ways that constantly challenge what appears normal and critique the ideologies that attempt to circumscribe my work. I am acutely aware that working at my university means working within a (power) structure which itself is being defined and shaped by an 'invisible' superstructure. The various leadership positions I have held as discipline head, cluster leader and head of school, senate representative, etc., have meant traversing a slippery slope; that is, the simultaneous movement between adherence (to policy) and activism. One quickly learns that overt activism (outspokenness) may have negative consequences. In the last 
decade, the increased movement towards prescription and narrowly defined performance expectations of academics has been particularly disconcerting. While it often feels as if one is swimming against an increasingly powerful tide, I have to remind myself to continue to attempt to fight the 'good fight' in ways that will not compromise me (or nullify my existence in the higher education space).

I remain hopeful and focus my efforts on how to work with my students towards sowing the seeds of a new generation of activists to counter the multitude of social justice issues that plague South African society (race, gender and economic prejudice).

\subsection{Tune 2}

Finding oneself in a liminal space often requires that earth dwellers - who are in existential terms always free to make choices despite the facticities that may limit their execution of - become objects in the world; objects without agency, objects left to the mercy of circumstance; a position described by Sartre (see Reynolds 2006) as self-deceiving. This is often the result of 'bad faith' in existentialist terms. Acting in bad faith is a denial of one's own freedom, using the very freedom bestowed upon the individual to perform such denial. One might wonder why I would start with bad faith. The reason is that on a historically white, Afrikaans-speaking university campus (like the one at which I am employed), early-career academics are frequently expected to assent to what they encounter; the discourses that undermine generative counter-narratives. Hence (like Sartre's example of the waiter) young academics often (deceivingly) perform their freedom of choice and in so doing mask themselves and/or (worst so) play a tacet role in the fugue. Tacets mark long periods of silence in music. What I soon realised was that my initial tacetness evoked responses and prepared me for moments of dissent (Du Preez 2019).

I was soon confronted with the liminal space between and within a complex nexus (a rhizome if you would like) of polyphonic and homophonic voices that I had to 'work through', when I accepted a variety of leadership roles. First as the subject group leader for Curriculum Studies; secondly, as the master's and doctoral programme leader (a position I currently hold); and thirdly, as the Research and Development coordinator in the Faculty. These positions have a common denominator: my role in terms of mentoring and 
capacity building amongst staff to increase their performativity, given the neo-liberal expectations set by the university and other statuary bodies that the university are subject to.

Introspection brought me to the realisation that I have always been prone to dissent through my overt outspokenness, which is in essence productive and generative. This stems from the inspiration I gained through prolonged engagement with issues of social justice - in terms of my own contrapuntal, polyphonic composition aired through my writing and deeply interwoven in my being. In largely conservative environments (such as the one I find myself in), dissent is often frowned upon: i.e. how do you dare to differ from the hegemonic, homophonic voice(s) of faculty? This is especially the case when one is in a leadership position. However, what I soon realised is that the generation and performance accompanying dissent is also complemented by tacet moments and intervals of homophony. Pitching oneself between and within spaces of assent and dissent - where inherent power relations cunningly infiltrate and operate - is challenging, as it elicits antagonism and the impossibility of reaching some form of consensus (Mouffe 2000a). This challenge is pivotal whenever pseudoreassurances of social cohesion (or social harmony) are uncritically accepted.

\subsection{Tune 3}

I am a woman who entered the academia at the age of 27 . I grew up in a middle-class family with liberal ideals and life philosophy. I went to boarding school from the age of five to 18 . Being taught to navigate life on my own has fuelled my passion for finding ways to survive and thrive in academia and life overall. I could be classified as a young to mid-career university academic as I was appointed into academia as a lecturer and promoted to associate professor by 33 . I have been employed by only one higher education institution, where I have occupied leadership positions such as a member of several committees, departmental chair, and a council member. My age and lack of teaching experience in schools have often cast a shadow of doubt on me. As an English-speaking lecturer, a tension presents when my liberal views sometimes clash with those of colleagues on this historically conservative, white, Afrikaans university campus. This has made me very conscious of my direct environment, because I have had to learn to channel my voice so it can be heard among my peers. My actions are 
also almost always preceded by self-debriefed introspection before navigating my institutional space.

I am often chastised for my ideas and the discourses they entertain because they go against the grain of long-standing traditions and dominant ideals. Being outvoted and overruled is an everyday experience. Nevertheless, I choose to use my presence as an embodied and embedded academic to trouble conventional curriculum thinking in the interests of the academic growth of my peers and myself as well as for the advancement of my field. My growth lies in being humble, but at the same time I remain obdurate and dedicated to perseverance for the sake of proactively participating in my field, not merely being a spectator. I also seek refuge and nourishment for my intellectual soul in like-minded academics who disrupt my thinking with the intent to expand it; a comradery that leaves me willing to expose my vulnerability so that together we can foster continuous moments of unlearning and relearning.

The lived curriculum as an interplay of assent and dissent is my space of continuous in-becoming. Its pathways often change direction and the destination remains unknown, but it engenders a deeply felt hunger for the type of change that learns from yesterday and lives for tomorrow to shape today.

\subsection{Tune 4}

As Connelly and Clandinin (1990) powerfully point out, human beings are storytelling beings because we live storied lives. My journey into higher education and the forming of my identity in a Faculty of Education commenced in 2000 when staff and students were predominantly white. Twenty years later, this is no longer the case. I am a South African male of mixed-race origin. My father, who was a school principal, was classified as 'Coloured' during the apartheid era, a term/categorisation that he rejected. My mother was an Indian who worked in her shop owned by her parents, who had emigrated from India to South Africa at the beginning of the $20^{\text {th }}$ century. As a young boy I grew up in a small village in the Kat River Valley approximately a three-hour drive from Port Elizabeth (Gqeberha). It was here where I first noticed the stark difference in the political reality between the white farmers in the area and the rest of the inhabitants and the workers they employed. Before I joined the Faculty of Education, I had taught for 17 years 
and had lived through the tumultuous period that followed the Soweto uprising in 1976. As a male who was not classified as White, I had to receive my university education at the University of the Western Cape in Cape Town, although the University of Port Elizabeth was right on my doorstep. This turned out to be a blessing in disguise, as it was at this university that my political awakening took place. The University of the Western Cape was known as the 'university of the left' in the 1980s. Here theory was not simply used for the sake of theory, but to critique some of the key policies and debates of that time. It was here where I was first introduced to progressive texts such as the works of Jürgen Habermas, Paulo Freire, Carr and Kemmis, Karl Marx, Bowles and Gintis. I flourished in this new-found freedom at university and most of my time was spent in the library where I devoured the banned/censored books that were accessible to students. During 1980, when I was a third-year student, the university experienced a three-month long student boycott as institutions throughout the country, including schools, came to a stand-still. One of the vivid and enduring memories of the time as I walked through the streets of Bellville was loud music blaring through speakers from a school yard playing to Pink Floyd's tune of 'We don't need no education' reaching a crescendo with 'hey teacher, leave those kids alone'. Those were heady days!

After I had left university, I started my teaching career in Port Elizabeth and became an activist involved in progressive teacher union politics. It was in the mid-1980s. Many of my colleagues and friends were detained by the apartheid police and were incarcerated for many months at a time. After spending 17 years at a high school, I joined a university located in the Eastern Cape Province. When I first joined the university, I always felt like an outsider looking in, as very few Black lecturers were employed in the Faculty of Education at the time, and the conservative climate that prevailed was informed by Fundamental Pedagogics. My teaching philosophy was diametrically opposite to most of my colleagues in the faculty. I embraced a teaching philosophy in which I regarded my task as raising difficult questions in class that confronted the South African society. In short, it can be characterised as 'teaching against the grain' or teaching for transgression. This was nothing new for me as a former history teacher at a high school where we always found ways to circumvent the prescribed curriculum to include progressive topics covering the resistance against apartheid in South Africa. Within a conservative faculty this approach held its own risks, as 
many of my colleagues at the time regarded/treated students as clients and avoided controversial topics. They were more concerned with/interested in securing good course evaluations from students. This critical attitude was a natural evolvement from my earlier days as a university student where most of our political learning took place during night discussions in residence rooms where we stayed. In 2016, this attitude did not make me too popular with university management when I questioned the performativity measures of the university in a Senate meeting.

In 2016, I was appointed into a management position in the Faculty of Education and it is in this capacity that my values and beliefs were often put to the test as (in this position) you are expected to advance certain strategic objectives of the university, which, at times, are not congruent with your own beliefs. As a leader, you have to navigate through this tricky area.

\subsection{Tune 5}

I was born in Cape Town in 1963, and classified 'Coloured' according to the Population Registration Act (No. 30 1950), promulgated by the apartheid government. Many continue to identify themselves as Coloured in postapartheid South Africa, but I do not. Learning about non-racism made me reject the imposed notion of 'Coloured'. During the school boycotts of 1980, when I was in Standard 9 (Grade 11), I attended alternative awareness programmes organised by the student representative council (SRC). Those programmes enabled us to learn the value of non-racism, and that we should not play multi-racial sport because there can be 'no normal sport in an abnormal society'. In the 1980 s, I joined many who boycotted establishment sport venues, including the Newlands Cricket and Rugby stadiums. This period as a school student marked the beginning of my critical consciousness and my valuing of dissent.

I did my BSc studies in the early to middle-1980s at what was then, arguably, one of the most radical universities in South Africa, the University of the Western Cape (UWC). My time at UWC was often 'interrupted' by student political activities such as public demonstrations, lecture boycotts and mass meetings. The political education I received during my studies at UWC, in the wake of the death of Steve Biko and rise of the United Democratic Front (UDF), led me to embrace blackness in the Black consciousness sense of the word. Taking on a black identity meant recognising 
the common experiences of all oppressed South Africans. I furthered my studies in education at the University of Cape Town (UCT). The liberal education I received there exposed me to disparate theories, including Critical Theory. I read the works of scholars like Paulo Freire, Henry Giroux, and Michael Apple. Through my engagement with these scholars' works and the classical sociologists, philosophers and psychologists I read during my undergraduate BA degree I began to develop the ability to express dissent through academic writing.

The period during my time as a university student and as a schoolteacher was a turbulent time in South Africa. Protests, marches and mass meetings characterised much of student life in the 1980s. Towards the end of the 1980s we had banned state officials (such as school inspectors and subject advisors) from our schools as their role was met with suspicion. But, for some of us it was not dissent without productive action. Through existing networks, as life sciences (biology at the time) teachers we organised and empowered ourselves by offering in-service teacher education 'for teachers by teachers'. This development marked a shift in my own professional journey to where dissent occurred through and in action.

When I began my academic career at a historically white and Afrikaans university 'dissent' was 'in my blood', because of my lived experiences of the struggle against apartheid. I came to value disagreement as long as it was accompanied by productive action. However, my dissent at the university was met with hostility from some colleagues. It denied me at least one promotion opportunity and was frowned upon because of a culture of 'politeness' (beleefdheid) that one experiences at historically White and Afrikaans universities - dissent is equated with rudeness.

Nevertheless, I soldiered on and voiced dissent in meetings, through resigning from certain university committees, through performing a pedagogy of disruption and through my academic writing that challenges the hegemony of Western thinking and knowledge. My dissent has been immanent to the molar identity of the university, which is White, male, Afrikaans, Christian, heterosexual and able-bodied, and more recently also to neoliberal influences on the university. But, in expressing my dissent I have been loyal to advancing the academic project through the different forms and functions of scholarship. While occupying leadership positions in the Faculty of Education, I have had to work at changing antagonism to agonism. 


\subsection{Tune 6}

A few weeks before writing this narrative I received an e-mail from our School administrator indicating the outcomes of the School Board election of professors into the promotions and selection committees. She indicated that I had received the highest number of votes and that I should accept this election. I then wondered how I had become someone that was so valued within the School despite being an Indian male professor, nearing retirement and who commenced working in higher education as a temporary appointed junior laboratory assistant in a historically Indian and disadvantaged university that eventually merged with a historically white university. Even more surprising was that when the merger between universities occurred, I was appointed to lead a School at the then Faculty of Education that had staff predominantly from the historically white university with a self-perception of superiority. Was it my leadership during periods of substantive change, my personality, my professionalism, my standing as an academic or was it that I was from a historically disadvantaged university? These 'why' questions may never be answered and as such it remains a quest. I had occupied almost all leadership positions within an academic unit of Education, including that of a Director of the School and as acting Dean.

I tried to make sense of this confidence in me after abruptly resigning from my last leadership position as a Cluster Leader within the School of Education at one of the School's executive meetings. At this meeting I spent approximately half an hour explaining why I had made this decision. It all started with my disgust at a decision made by the School's appeals committee wherein clear injustice was committed. Students who do not satisfy the duly performed (DP) requirements are not allowed to write their final examinations, but they have an opportunity to appeal the decision. On reviewing the outcome of the appeals process, I was taken aback at the profile of the students who were unsuccessful in their appeals, all of whom belonged to a single apartheid-based racial group. This incident took me back to the dark days of discrimination during apartheid, but this time not by the White dominance over the other racial groups. I used my leadership position as a conduit of dissent and at this particular executive meeting I took the opportunity to express my feelings on other growing issues of discrimination, including that of discriminating against senior academics of the School. My disgust was against any form of discrimination, which as student activist, I 
had fought against during the apartheid regime. Since then, there were many more incidences of productive dissent against discrimination in any form and this is perhaps what I believe led to me regaining the confidence of the majority of staff within the School.

\section{Contrapuntal, Polyphonic Composition - A Tuning in ...}

Having presented the six tunes, we each shall perform rhizomatically to weave our tuned experiences diffractively. We 'tune in' by bringing our unique tunes into conversation with each other - to generate a new fugue, rather than represent one tune in search of a master narrative that can draw grand conclusions. Our contrapuntal composition entertains different lines of flight in an attempt at the ambitious and insolvable - namely, to tease out the concept dissent vis-à-vis the neoliberal university as one avenue to challenge liberal democratic notions of social cohesion, towards an agonistic deliberative that might be more productive.

Agony;

heard when assent is normalised, institutionalised ...

Agony;

voiced by those who sing along - ever so decent, ever so complacent and more so: entangled in tacit self-induced torture; indoctrinated ...

Interlude: Some songs remain unsung (forever) - completely tacet... Poor souls hymning along those empty, representational lines!

Others are meant to be heard - immersed, embodied, embrained - a (potentially) performative asset ...

Introspective souls, striking the bell, using conductors' wands as chimes ...

Pure agony; enslaved and tormented for straying from monotonous mainstream tunes ...

Pure agony; fearless outspokenness about difference: a difference that discriminates!

Interlude: Some songs (all too familiar to us) are stringed together - letters, words, lines, rhythmic lyrics - classics they say! (... Neatly packaged so that nothing goes astray ...) 
Songs less sung - songs that rock and roll-scraping at the end of one's tether

- gaining a deafening strength to 'go against the grain' - risky (they say) all along the way!

polyphonic, contrapuntal melodies: sounds that can distort, notes that should dis(inter)rupt melodic parodies ... a disposition of some sort?

Alas!

An agonistic disposition - in its purest form - a crucial virtue: (one that can curb you and/ or one that should disturb you ...)

Catechise classical beliefs about metaphoric dreams! Deprecate taken-for-granted democratic schemes!

Express dissatisfaction!

Embrace dubitation!

$$
\begin{gathered}
\text { Alas! } \\
\text { In its purest form - an agonistic disposition, } \\
\text { inevitable for social cohesion: } \\
\text { a pipe-dream virtue, } \\
\text { whose silence must've burned you (?) }
\end{gathered}
$$

\section{(The in-between narration ...)}

... Agony, discomfort and ability to make choices as academics and leaders within higher education spaces in a rapidly changing performative environment created opportunities to slip between adherence and activism. But the agony, discomfort and ability to make these choices just did not happen. Early exposure to the counter-narrative discourses in a conflicting national context engendered a latent but potent positionality as academics and leaders within academic spaces, including that of being in and out of positions of power, to continually pursue dissent as potential for change. The mediating moments of the liminal space in-between positions of power within higher education spaces were moments of introspection and remaining hopeful about the project of positive dissent for social change ... 


\section{POINT OF INTERJECTION, THE NEED TO PAUSE:}

\subsection{The Divas}

Divas, more commonly referred to as opera singers, are renowned for their talent. A diva can also be a description given to a person who is demanding, bossy and spoiled and likes to call the tune. The neoliberal higher education space presents various divas. Our being and becoming as academics means that we must confront these divas at times - sometimes we must sing along and at other times we must stamp our feet. If we look the monster (with its various divas) in the eye, will that deter it? Or will it make it angry and more belligerent? Or both? And who is impacted by its reaction(s)?

\subsection{Hope}

Some of our tunes (narratives) have proffered the need to remain hopeful. Is being hopeful enough when we have to face the divas in our midst? Could hope not easily be a scapegoat? Or could hope not have the potential to turn us into 'fence-sitters' who wait it out and allow academia to continue to deceive us? The neoliberal empire manipulates us like puppets on a string while we are made to believe academics should rejoice as they have so-called voice and choice. Is hope not another form of assent? When is hope generative and not complacent or merely vested in a dream of what could be or should become? How might we (higher education academics) discern a critical hope (Bozalek et al. 2014) as active construct that invokes critical judgement in the face of despair?

Could dissent and agonism create moments where we can pause our melody and contemplate issues such as the divas we face and the (false) hope that is created or that we create? Issues such as these that have no Grammy Awards because their songs are not stories told and recorded, but the lyrics of lives being lived and changed continuously.

A discordant-harmonious melody continued ....

The very particular histories revealed in these tunes suggest that it is real and that it will be with their carriers for some time, if not for a lifetime. With the passage of time it could gradually recede into the past and the 
project of social cohesion would be kept alive. What would serve our generation best is to honour (or pay allegiance to) both our histories as well as the aspirational political goal of social cohesion; hence our argument to resolve nothing (agonism) and instead leave these rhizomatic lines of flight open to develop in directions that are not yet known or definite (both dissent and allegiance co-exist). Viewed thus, it then does not become a grand or hegemonic narrative that will be congruent or better aligned with a complex and diverse society. Social cohesion understood in these terms then becomes an evolving and open construct that plays out amidst these complex histories that extend into the future into the modern neo-liberal state. More particularly, they extend into higher education where our identities are lived and experienced at present. The other alternative suggests a premature closure and renders any other option impossible; the histories that are part of our memories and are not confronted by the tangible and overt apartheid state today, but are represented by the neo-liberal state. Together this polyphonic, contrapuntal melody, just like an orchestra, is characteristic of the diverse plural society we live in. We must conceptualise social cohesion differently - rather than one of perfect harmony - as one akin to an orchestra where the unique instruments contribute to the overall melody. These tunes can either stay intact or change, where the possibility is left open for it to morph into something new - something not foreseen by us. These polyphonic, contrapuntal tunes suggest that social cohesion will be constructed from below rather than being imposed from the top.

\subsection{Making Sense of the Fugue (Assemblage)}

Our article is an assemblage, an ensemble, a fugue. It connects ideas, life histories, people (the authors of article and the authors that they cite/quote) and places in multiple ways. The assemblage is a rhizome with a myriad of potential connections that can be enlivened by the melodic lines captured in the experiences of the authors, their life histories and theories. It is not a treearticle that mimics the typical genre of the journal article. As was the case with Deleuze and Guattari's (1987) assemblage, A Thousand Plateaus, the authors, the sections of the article and the theories being engaged with may be out of rhythm or out of step. And the dissent itself, is a phenomenon out of rhythm and out of step with what has become sedimented/ hegemonic.

As the melodic waves of the tunes presented by the different authors 
overlap, we see recurring melodic lines, which are characteristic of a fugue. However, Deleuze and Guattari (1987) remind us that the refrain (la ritournelle) is creative and not banal. Refrains produce intensities/difference (Deleuze 2001). So rather than do what common sense might tell us, we have not abstracted what appears to converge. Instead we invite the reader to see the refrains as creating intensities - creating different realities of what it is to be an academic in a divided world/country and in the neoliberal university. This rhizome-article depicts difference in multiple ways. We have experimented with the real, and education and educational research is nothing more or less than a lifelong affair of experimentation (Le Grange 2018b).

\subsection{Tuning out ...}

We continue to bite the hand that feeds us, responding to the inspiring appeal from Eve Tuck (Unangax). Despite declaring that there 'are parts of the higher education project that are too invested in settler colonialism to be rescued', she also contends that there 'are parts of academic labour that might be refused in order to generate new possibilities' (Tuck 2018:149). The recognition that South African universities remain sites of the grand colonial project that is mutating 'naturally' into a corporatised space, strengthens our suspicion that social cohesion initiatives are merely ideological hoodwinking. We argue instead for a refusal (of the university) (Grande 2018). Although Tuck (2018) and Grande (2018) write specifically about the ongoing social justice project of indigenous peoples of the Americas (and their activism in academia), their insights have particular resonance for the South African higher education context.

An antagonistic disposition continues to serve us well. Jones (2014:2) reminds us that antagonism is an 'inescapable' aspect of political activism, which is 'always an act of power' and central to the constant (re)creation of identity. In challenging Deleuze and Guattari's notion of how power flows, Tuck (2018:161) asserts that 'power is social, it is agentic'. As such it is certainly located within us - what we need to do is to renew the careful attentiveness that appears to have waned during the euphoric dawn of democracy in South Africa. Standing in the path of substantive decolonisation of the higher education space is a set of neo-colonialists, newly converted disciples that oversee a new neoliberal disciplinary regime, 
adversaries that must be engaged. Mouffe's notion of agonal respect speaks directly to (one's) conduct in an adversarial relationship that is based on a predetermined set of rules. Navigating this adversarial relationship is precarious and paradoxical and might even be considered contradictory to dissent as ethical and immanent to being and becoming, as one pursues the 'struggle' within circumscribed parameters. Occupying such a dissonant space might mean attempting an emancipatory agonism (Mouffe 2005) through a process of deliberately constructing adversarial relationships, yet holding a commitment to a mutuality of benefit and conflictual consensus (Jones 2014). It might entail making peace with a diluted level of agreement while constantly advocating for a Mouffe-inspired pluralism (Mouffe 2000b).

\section{An Invitation}

In this article, we have tried to break the frame, to experiment with a different way of performing educational inquiry. Like us, the concepts and theories we think with are in-becoming. Even the figuration fugue we experiment with might become other, more akin to jazz improvisation. We invite the reader to think with us, to experiment with us, and to become part of an ensemble that is in motion.

\section{References}

Anzaldúa, G.E. 1987. Borderlands/ La Frontera: The New Mestiza. San Francisco: Aunt Lute Book Company.

Aronsson L. \& H. Taguchi 2018. Mapping a Collaborative Cartography of the Encounters Between the Neurosciences and Early Childhood Education Practices. Discourse: Studies in the Cultural Politics of Education 39,2: 242 - 257.

https://doi.org/10.1080/01596306.2017.1396732

Barad, K. 2007. Meeting the Universe Halfway: Quantum Physics and the Entanglement of Matter and Meaning. Durham \& London: Duke University Press. https://doi.org/10.2307/j.ctv12101zq

Bozalek, V., B. Leibowitz, R. Carolissen \& M. Boler (eds.). 2014. Discerning Critical Hope in Educational Practices. Abingdon, England: 
Suriamurthee Moonsamy Maistry et al.

Routledge. https://doi.org/10.4324/9780203431115

PMid:23574731 PMCid:PMC3635913

Braidotti, R. (ed.). 2013. The Posthuman. Cambridge: Polity Press.

Brown, R. (ed.). 2011. Higher Education and the Market. New York:

Routledge. https://doi.org/10.4324/9780203849002

Connelly, F.M. \& D.J. Clandinin 1990. Stories of Experience and Narrative

Inquiry. Educational Researcher 19,15: 2 - 24.

https://doi.org/10.3102/0013189X019005002

Deleuze, G. 2001. Difference and Repetition. Patton, P. (trans.). London \&

New York: Continuum.

Deleuze, G. \& F. Guattari 1987. A Thousand Plateaus: Capitalism and

Schizophrenia. Massumi, B. (trans.). Minneapolis: University of

Minnesota Press.

Du Preez, P. 2019. Nostalgia, Dialogue and Silence: On the Ethics of Curriculum Studies. Inaugural address delivered on 14 August 2019.

North-West University, Potchefstroom, South Africa.

Fanelli, C. \& B. Evans 2015. Neoliberalism and the Degradation of Education. Alternate Routes: A Journal of Critical Social Research 26. Grande, S. 2018. Refusing the University. In Spooner, M. \& J. McNinch (eds): Dissident Knowledge in Higher Education. Saskatchewan: University of Regina Press.

Habermas, J. 1996. Between Facts and Norms: Contributions to a Discourse Theory of Law and Democracy. Rehg, W. (trans.). Cambridge, MA:

MIT Press. https://doi.org/10.7551/mitpress/1564.001.0001

PMid:9156686

Habib, A. 2013. South Africa's Suspended Revolution: Hopes and Prospects.

Johannesburg: Wits University Press.

https://doi.org/10.18772/12013086086

Harvey, K. 2012. Democratic Agonism: Conflict and Contestation in Divided Societies. E-International Relations. Available at:

https://www.e-ir.info/2012/10/20/democratic-agonism-conflict-andcontestation-in-divided-societies/ (Accessed on 21 January 2021.)

Hepler, S., S. Cannon, C. Hartnett, \& T. Peitso-Holbrook 2019. Undoing and Doing-with: Practices of Diffractive Reading and Writing in Higher Education (viewpoint). In Taylor, C. \& A. Bayley (eds): Posthumanism and Higher Education: Reimagining Pedagogy, Practice and Research. Switzerland: Palgrave Macmillan. 
Why Dissent/ Agonism Might have Appeal in a Neoliberal HE Space!

https://doi.org/10.1007/978-3-030-14672-6 8

Hill, C.M. 2017. More-than-reflective Practice: Becoming a Diffractive Practitioner. Teacher Learning and Professional Development 2,1: 1 17.

Jackson, A. \& L. Mazzei 2012. Thinking with Theory in Qualitative Research. Viewing Data Across Multiple Perspectives. New York: Routledge.

Jansen, J.D. 2017. As by Fire: The End of the South African University. Cape Town: Tafelberg.

Jones, M. 2014. Chantal Mouffe's Agonistic Project: Passions and Participation. Parralax 20: $14-30$.

https://doi.org/10.1080/13534645.2014.896546

Jones, S. \& T. Adams 2014. Undoing the Alphabet: A Queer Fugue on Grief and Forgiveness. Cultural Studies 14,2: $102-110$.

https://doi.org/10.1177/1532708613512260

Kumm, B. \& L. Berbary 2018. Questions for Postqualitative Inquiry: Conversations to Come. Leisure Sciences 40,1-2: $71-84$. https://doi.org/10.1080/01490400.2017.1376014

Lange, L. 2014. Rethinking Transformation and Its Knowledge(s): The Case of South African Higher Education. Critical Studies in Teaching and Learning 2,1: $1-24$.

Lather, P. 1994. Fertile Obsession: Validity after Poststructuralism. In Gitlin, A. (ed.): Power and Method: Political Activism and Educational Research. London: Routledge.

Lather, P. 2013. Methodology-21: What Do We Do In The Afterward? International Journal of Qualitative Studies in Education 26,6: 634 645. https://doi.org/10.1080/09518398.2013.788753

Le Grange, L. 2011. Sustainability and Higher Education: From Arborescent to Rhizomatic Thinking. Educational Philosophy and Theory 43,7: $742-754$.

https://doi.org/10.1111/j.1469-5812.2008.00503.x

Le Grange, L. 2018a. What Is (Post)Qualitative Research? South African Journal of Higher Education 32,5: 1 - 14.

https://doi.org/10.20853/32-5-3161

Le Grange, L. 2018b. Spinoza, Deep Ecology and Education Informed by a (Post)human Sensibility. Educational Philosophy and Theory 50,9: 878 - 887. https://doi.org/10.1080/00131857.2017.1384723 
Suriamurthee Moonsamy Maistry et al.

McDonough, G.P. 2010. Why Dissent is a Vital Concept in Moral Education. Journal of Moral Education 39,4: 421 - 436.

https://doi.org/10.1080/03057240.2010.521373

Mouffe, C. 2000a. Deliberative Democracy or Agonistic Pluralism. Political Science Series 72: $1-31$.

Mouffe, C. 2000b. The Democratic Paradox. London: Verso.

Mouffe, C. 2005. On the Political. London: Routledge.

Mouffe. C. 2013. Agonistics: Thinking the World Politically. London: Verso. The Population Registration Act of South Africa 1950. Pretoria: Government Printer.

Reynolds, J. 2006. Understanding Existentialism. London \& New York: Routledge.

https://doi.org/10.1017/UPO9781844653690

Singh, S. 2012. Re-inserting the 'Public Good' into Higher Education

Transformation. In Leibowitz, B. (ed.): Higher Education for the Public

Good: Views from the South. Cape Town: Trenthan Books with Sun

Press. https://doi.org/10.18820/9781928357056/01

Spinoza, B. 2001. Ethics. White, W.H. (trans.). Wordsworth: Hertfordshire. Tuck, E. 2018. Biting the University that Feeds Us. In Spooner, M. \& J. McNinch (eds): Dissident Knowledge in Higher Education. Saskatchewan: University of Regina Press.

Tully, J. 1999. The Agonic Freedom of Citizens. Economy and Society 28,2: $161-182$.

https://doi.org/10.1080/03085149900000001

Van Niekerk, R. \& V. Padayachee 2019. Shadow of Liberation: Contestation and Compromise in the Economic and Social Policy of the African National Congress, 1943 - 1996. Johannesburg: Wits University Press. https://doi.org/10.18772/12019103955

Zulu, P. 2013. A Nation in Crisis: An Appeal for Morality. Cape Town: Tafelberg.

Professor Suriamurthee Moonsamy Maistry Social Sciences Education University of KwaZulu-Natal Durban maistrys@ukzn.ac.za 
Why Dissent/ Agonism Might have Appeal in a Neoliberal HE Space!

Professor Sylvan Blignaut Postgraduate Studies Department (Faculty of Education)

Nelson Mandela University Port Elizabeth sylvan.blignaut@mandela.ac.za

Professor Petro Du Preez Curriculum Studies North-West University Potchefstroom

Petro.DuPreez@nwu.ac.za

Distinguished Professor Lesley Le Grange Curriculum Studies Stellenbosch University Stellenbosch llg@sun.ac.za

Professor Labby Ramrathan Education Studies University of KwaZulu-Natal Durban ramrathanp@ukzn.ac.za

Associate Professor Shan Simmonds Education and Human Rights in Diversity (Edu-HRight) Research Unit North-West University Potchefstroom shan.simmonds@nwu.ac.za 